\title{
Technology generation to dissemination: lessons learned from the tef improvement project
}

\author{
Gina Cannarozzi - Solomon Chanyalew $\cdot$ Kebebew Assefa - Abate Bekele \\ Regula Blösch • Annett Weichert • Dominik Klauser - Sonia Plaza-Wüthrich • \\ Korinna Esfeld • Moritz Jöst • Abiel Rindisbacher · Habte Jifar • \\ Victoria Johnson-Chadwick - Ermias Abate - Wuyan Wang - Rizqah Kamies • \\ Negussu Husein - Worku Kebede - Kidist Tolosa - Yazachew Genet • \\ Kidu Gebremeskel • Brikti Ferede $\cdot$ Firew Mekbib • Federico Martinelli • \\ Hans Christian Pedersen - Suhail Rafudeen - Shimelis Hussein • \\ Muluneh Tamiru • Naomi Nakayama • Mike Robinson • Ian Barker • \\ Samuel Zeeman $\cdot$ Zerihun Tadele $\mathbb{C}$
}

Received: 24 December 2016/ Accepted: 16 January 2018/Published online: 23 January 2018

(C) The Author(s) 2018. This article is an open access publication

\begin{abstract}
Indigenous crops also known as orphan crops are key contributors to food security, which is becoming increasingly vulnerable with the current trend of population growth and climate change. They have the major advantage that they fit well into the general socio-economic and ecological context of
\end{abstract}

This article is part of the Topical Collection on Plant Breeding: the Art of Bringing Science to Life. Highlights of the 20th EUCARPIA General Congress, Zurich, Switzerland,

29 August-1 September 2016

Edited by Roland Kölliker, Richard G. F. Visser, Achim Walter \& Beat Boller

G. Cannarozzi · R. Blösch · A. Weichert .

S. Plaza-Wüthrich · K. Esfeld · M. Jöst ·

A. Rindisbacher $\cdot$ Z. Tadele $(\square)$

University of Bern, Institute of Plant Sciences,

Altenbergrain 21, 3013 Bern, Switzerland

e-mail: zerihun.tadele@ips.unibe.ch

S. Chanyalew $\cdot$ K. Assefa $\cdot$ A. Bekele $\cdot$

N. Husein · W. Kebede · K. Tolosa · Y. Genet

Ethiopian Institute of Agricultural Research, Debre Zeit

Agricultural Research Center, P.O. Box 32, Debre Zeit,

Ethiopia

D. Klauser · V. Johnson-Chadwick ·

M. Robinson · I. Barker

Syngenta Foundation for Sustainable Agriculture, WRO-

1.4.10, Schwarzwaldallee 215, 4058 Basel, Switzerland developing world agriculture. However, most indigenous crops did not benefit from the Green Revolution, which dramatically increased the yield of major crops such as wheat and rice. Here, we describe the Tef Improvement Project, which employs both conventional- and molecular-breeding techniques to improve tef-an orphan crop important to the food security in the Horn of Africa, a region of the world with recurring devastating famines. We have established an efficient pipeline to bring improved tef lines from the laboratory to the farmers of Ethiopia. Of critical importance to the long-term success of this project is

H. Jifar

Ethiopian Institute of Research, Holetta Agricultural

Research Center, P.O. Box 31, Holetta, Ethiopia

E. Abate

Amhara Regional Agricultural Research Institute,

P.O. Box 527, Bahir Dar, Ethiopia

W. Wang $\cdot$ S. Zeeman

ETH Zurich, Institute of Molecular Plant Biology,

Universitätstrasse 2, 8092 Zurich, Switzerland

R. Kamies · S. Rafudeen

Department of Molecular and Cell Biology, Plant Stress

Lab, University of Cape Town, Private Bag,

Rondebosch 7701, South Africa 
the cooperation among participants in Ethiopia and Switzerland, including donors, policy makers, research institutions, and farmers. Together, European and African scientists have developed a pipeline using breeding and genomic tools to improve the orphan crop tef and bring new cultivars to the farmers in Ethiopia. We highlight a new variety, Tesfa, developed in this pipeline and possessing a novel and desirable combination of traits. Tesfa's recent approval for release illustrates the success of the project and marks a milestone as it is the first variety (of many in the pipeline) to be released.

Keywords Eragrostis tef - Marker-assisted breeding · Orphan crops · Tef · TILLING · Farmerparticipatory research

\section{Introduction}

Orphan crops, also known as under-researched crops, play a particularly important role in food security, nutrition, and income generation for resource-poor farmers and consumers in developing countries, especially in Africa. These crops perform better than the major crops of the world under the extreme soil and

K. Gebremeskel

Tigray Agricultural Research Institute, Axsum Agricultural Research Center, P.O. Box 230, Axum, Ethiopia

B. Ferede

Department of Plant Sciences, Asosa University, P.O.Box 18, Asosa, Ethiopia

F. Mekbib

Haramaya University, P.O. BOX 138, Dire Dawa, Ethiopia

F. Martinelli

Dipartimento di Scienze Agrarie e Forestali, viale delle scienze Ed. 4, 90128 Palermo, Italy

H. C. Pedersen

Maribo Seed International ApS, Højbygårdvej 31, 4960 Holeby, Denmark

S. Hussein African Center for Crop Improvement, University of KwaZulu-Natal, Private Bag X01,

Scottsville 3209, Pietermaritzburg, South Africa climatic conditions prevalent in the developing world. Orphan crops are also compatible with the agroecology and socio-economic conditions of the regions in which they originate and are grown.

African orphan crops have a number of advantages in terms of adapting to adverse climatic and soil conditions. Among cereals, finger millet (Eleusine coracana), fonio (Digitaria exilis and D. iburua), and African rice (Oryza glaberrima) are well adapted to drought-prone areas where moisture is low and are able to sustain normal growth until maturity (NAP 1996; Williams and Haq 2000). Due to their earlymaturing properties, most of these crops are the main source of food during critical food shortage periods, particularly the time just before most crops are ready for harvest. Among widely cultivated legumes in Africa, cowpea (Vigna unguiculata) is tolerant to drought and heat and grows quickly (Valenzuela and Smith 2002) while grass pea (Lathyrus sativus) is considered to be an insurance crop since it produces reliable yields when all other crops fail due to extreme drought. Similarly, several indigenous root crops cultivated in Africa are also resilient to diverse environmental stresses.

In addition to their significant economic importance, African crops provide a nutritive and healthy diet. For instance, the seeds of fonio are nutritious and

M. Tamiru

Department of Animal, Plant and Soil Sciences, Centre for AgriBioscience, La Trobe University, 5 Ring Road, Bundoora, Melbourne, Australia

N. Nakayama

University of Edinburgh, Max Born Crescent, Edinburgh EH9 3BF, UK

Z. Tadele

Centre for Development and Environment (CDE), University of Bern, Hallerstrasse 10, 3012 Bern, Switzerland

Z. Tadele

Institute of Biotechnology, Addis Ababa University, P.O. Box 32853, Addis Ababa, Ethiopia 
notably rich in methionine and cysteine, two amino acids essential for human health but deficient in major cereals such as wheat, rice and maize (IPGRI 2004). Bambara groundnut (Vigna subterranean) is unique since it contains adequate quantities of protein (19\%), carbohydrate (63\%), and fat (6.5\%) (NAP 2006). Finger millet is a popular food among diabetic patients because of its slow digestion and low glycemic index (Chandrashekar 2010). Finger- and pearl-millets have anti-cell-proliferative properties, and might have a potential in the prevention of cancer initiation (Chandrasekara and Shahidi 2011). The orange pulp type banana has high carotenoid and iron contents. It's incorporation into the diets in East Africa has been shown to reduce Iron Deficiency Anemia (IDA) by over 50\% and effectively combat Vitamin A Deficiency (VAD), both of which affect a large percentage of the population (Fungo 2009).

Although African indigenous crops perform better than major crops of the world under extreme environmental conditions and fit to the socio-economic conditions of the areas in which they are grown, they also encounter a number of constraints. The major bottleneck is related to the dearth of genetic investigations made on these crops. Almost all orphan crops are being studied by poorly funded researchers based in resource-limited developing nations. The majority of these researchers have little chance to establish partnerships with the scientific community especially with those in the developed world. Modern improvement techniques are rarely employed in orphan crops, while breeding is mostly dependent on the conventional improvement techniques such as selection and hybridization. Only limited numbers of breeders implement modern techniques such as marker-assisted breeding. Genomic information such as whole-genome sequencing is not yet available for most orphan crops.

The famous Green Revolution, which contributed to a significant boost in crop production and productivity in Asia, did not occur in Africa, mainly due to the exclusion of major African staple food crops as a primary focus of improvement (Ejeta 2010; Godfray et al. 2010). In terms of area of cultivation, the top three crops in Africa are maize, sorghum and millet, while in Asia they are rice, wheat and maize in descending order (FAOSTAT 2016). Investment in research and development especially in human resources and infrastructure are also low in Africa.
Although African countries agreed to allocate at least $10 \%$ of their national budgetary resources to agriculture and rural development policy implementation, only few countries have reached the target (AU 2005).

This review describes the structure and progress of an initiative to improve tef, one of the most important indigenous and understudied crops in the Horn of Africa. The Tef Improvement Project (TIP) brings together scientists, charitable organizations, business leaders and development workers from different countries and institutions for the common goal of providing new improved tef cultivars to farmers in a timely manner. In this review paper, we show that by working together with different stakeholders in a value-chain approach from basic research at the University of Bern to variety development and dissemination in Ethiopia, we can contribute to raising productivity of under-researched crops like tef. The system which we have established can be applied to other systems and crops.

\section{Tef: a crop of choice for scientific research}

Tef [Eragrostis tef (Zucc.) Trotter] is the most important cereal crop in the Horn of Africa, especially in Ethiopia, where the last two decades have seen tremendous increases in both the total area devoted to the crop and its production (Fig. 1a). It is annually cultivated on over three million hectares of land, which is equivalent to $30 \%$ of the total area allocated to cereals (CSA 2015) (Fig. 1b). Tef is preferred both by farmers and consumers. Farmers prefer cultivating tef to other cereals since it is more resilient to environmental stresses such as poor soil drainage during the rainy season and moisture scarcity. In addition, as a cash crop, both the grain and straw of tef fetch higher prices than the respective products from other cereals. Consumers prefer tef not only because it makes good quality "injera", a pancake-like soft bread, but also because it is nutritious due to its high protein and mineral content (Bultosa et al. 2002; Abebe et al. 2007). Furthermore, the absence of gluten (Spaenij-Dekking et al. 2005) makes tef an alternative food for people suffering from celiac disease. Due to this life-style feature of the crop, it has been heralded as a 'superfood' or 'super grain' (Jeffrey 2015; Provost and Jobson 2014). Overall, tef plays a vital role in food 
Fig. 1 Importance and constrains of tef cultivation in Ethiopia. a both the total area and the total grain production of tef have significantly increased in the last two decades; $\mathbf{b}$ tef occupies the highest proportion of cereal area; c the productivity per unit area was the lowest for tef compared to other cereals. Lodging or susceptibility of the plant to fall over on the ground $\mathbf{d}$ and drought $\mathbf{e}$ are major constraints to increasing tef productivity. b, c are from 2014. ac adapted from CSA reports
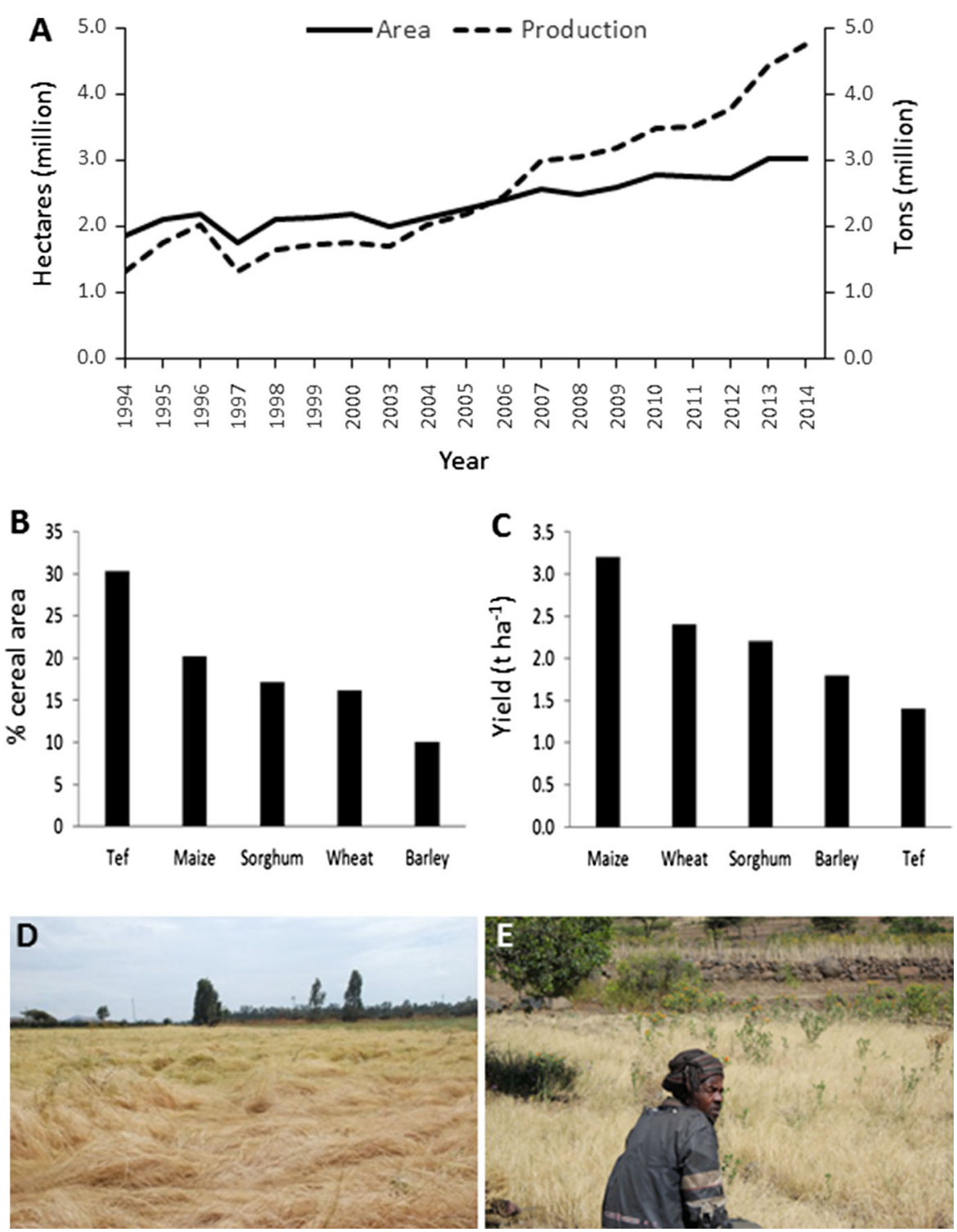

security, nutrition, and income generation to smallholder farmers in Ethiopia.

Despite its versatility in adapting to extreme environmental conditions, the productivity of tef is low in Ethiopia at 1.5 tons $\mathrm{ha}^{-1}$ as compared to 3.2 tons $\mathrm{ha}^{-1}$ for maize (CSA 2015) (Fig. 1c). The major yield-limiting factors to tef production are the lack of cultivars tolerant to lodging and to prolonged drought (Assefa et al. 2011) (Fig. 1d, e), as well as tef's small seed size. The low productivity is also related to the widespread use of landraces and cultivars lacking desirable agronomic traits.
Lodging (permanent displacement of the stem from the upright position) is the major production constraint in tef. Tef possesses tall and weak stems that easily succumb to lodging caused by wind or rain. In addition, lodging hinders the use of high input husbandry since increasing the amounts of nitrogen fertilizer to boost the yield also exacerbates the lodging problem. Consequently, both the yield and the quality of the grain and the straw are severely reduced. Lodged plants are difficult to harvest manually and make mechanical harvesting impossible.

Genomic information such as whole-genome sequencing has not been available until recently for 
most orphan crops including tef, a self-pollinated, allotetraploid plant for which the true diploid ancestors are not yet known. Since the genomic sequences of grass family members are somewhat conserved, interesting genes from orphan crops can sometimes be identified from orthologous genes in related crops. The phylogenetic tree of the grass family in Fig. 2 shows the relationship of tef to other cereals. Finger millet is the most closely related crop to tef as they both belong to the subfamily Chloridoideae. Until the completion of the genome sequencing in 2014 (Cannarozzi et al. 2014), the lack of genomic sequences for both finger millet and tef was the major limitation in using genomic tools in tef breeding.

In general, tef is a prime example of an understudied orphan crop since little scientific improvement has been made on the crop compared to the globally major crops such as maize, wheat and rice. This makes tef an attractive target for the implementation of hightech breeding and genomic strategies. To this end, the Tef Improvement Project was established in July 2006 with the financial support from the Syngenta Foundation for Sustainable Agriculture and the University of Bern in Switzerland, and is hosted at the Institute of Plant Sciences at the University of Bern.

\section{The tef improvement project: goals and strategy}

The main aim of the Tef Improvement Project is to boost the productivity of tef by tackling major production constraints through developing cultivars with desirable agronomic and nutritional traits. Hence, the project focuses on problem-oriented or demanddriven research. Specific objectives of the project are:

(i) To develop tef cultivars with desirable traits using diverse improvement techniques. Priority has been given to lodging and drought, both of which contribute to significant yield loss in tef production.

(ii) To sequence the genome and transcriptome of tef for use in marker-assisted breeding and high throughput screenings.

(iii) To study diversity in tef accessions with the aim of identifying natural variation in relevant traits.

(iv) To disseminate new tef varieties with improved traits to the Ethiopian farming community.

(v) To contribute to the human capacity building of the Ethiopian Agricultural Research System.
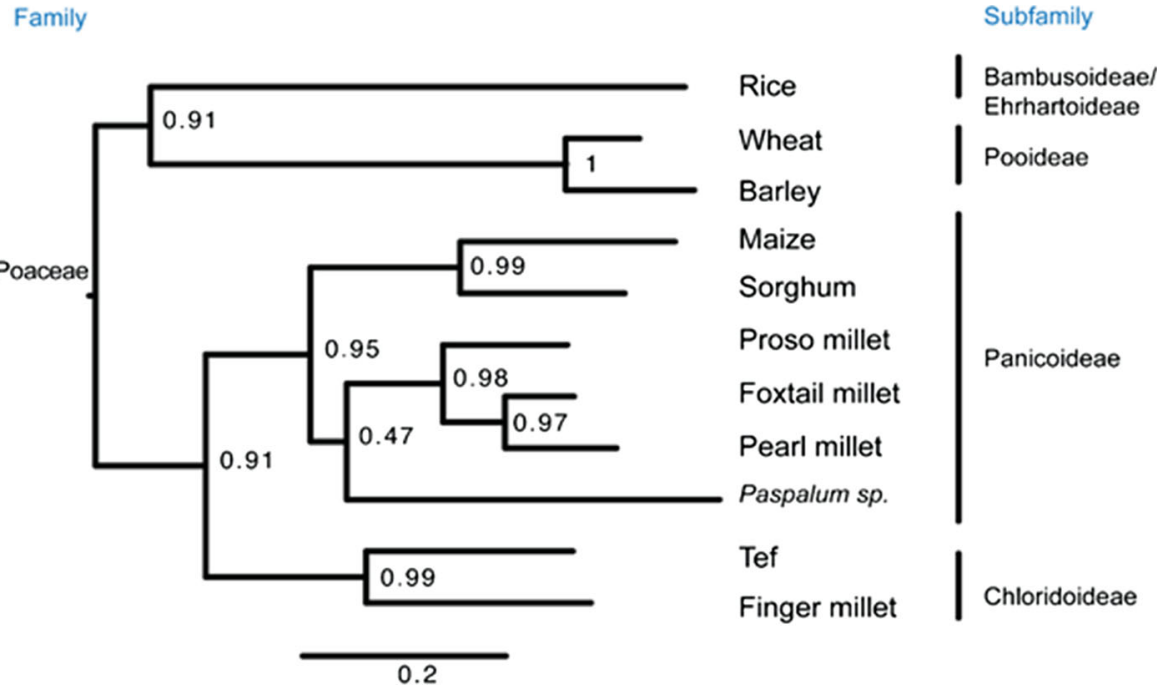

Fig. 2 Phylogenetic tree showing the molecular relationships of tef to other cereals. The tree was constructed using Waxy gene from rice (Oryza sativa, AF51548), bread wheat (Triticum aestivum, HQ338714), barley (Hordeum vulgare, GU599884), maize (Zea mays, EU041692), sorghum (Sorghum bicolor,
EF089839), proso millet (Panicum miliaceum, GU199268), foxtail millet (Setaria italica, AB089143), pearl millet (Pennisetum glaucum, AF488414), Paspalum simplex (AF318770), tef (Eragrostis tef, AY136935), and finger millet (Eleusine coracana, AY508652) 
The strategy and pipeline to develop new tef cultivars with valuable traits and to move the new cultivars to the field in Ethiopia are shown in Fig. 3. In the Technology Generation process, the project applies modern genetic, molecular and genomic tools to obtain candidate tef lines for the diverse goals of the project. In the Forward Genetics approach, the mutagenized tef population is used for phenotypic screening in order to obtain candidate mutant lines for the traits of interest. Moreover, the same populations are used in Reverse Genetics approaches such as TILLING (Targeting Induced Local Lesions IN Genomes) to screen for mutant lines that harbor DNA lesions in genes of interest. In the Technology Transfer phase, promising tef lines harboring traits of choice are sent to the Ethiopian Institute of Agricultural Research where they are introgressed into high-yielding and widely adapted cultivars and evaluated for several generations at the on-station and on-farm sites across Ethiopia before release to the farming community. The project is also involved in capacity building through short- and long-term trainings, workshop organization and provision of research supplies. In the Technology Delivery phase, seeds of newly released varieties are multiplied and disseminated through private and public institutions. The project also focuses on the scaling-up of improved tef technologies where model farmers with know-how in the handling

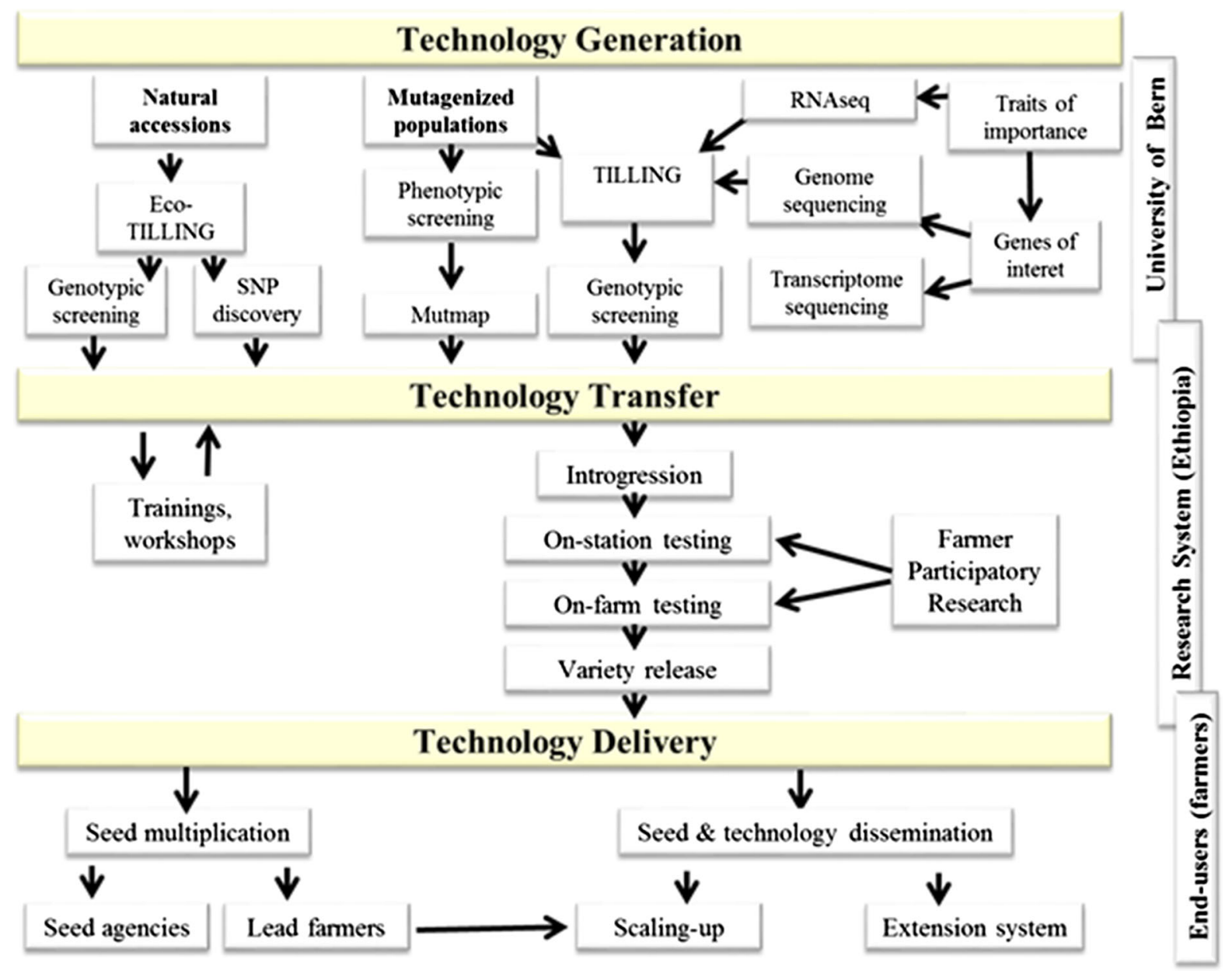

Fig. 3 Strategies and activities of the Tef Improvement Project. The first phase involves technology generation wherein improved cultivars are developed or methods are optimized. In the second phase, promising materials are introgressed to locally-adapted and high-yielding varieties and field-tested in
Ethiopia. Technology delivery refers to both seed multiplication and dissemination as well as dissemination to key partners. The project is also involved in human-resource development through short- and long-term training 
of improved seeds play key roles in multiplying and disseminating of seeds and knowledge to fellow farmers.

\section{Tools and resources for technology generation}

The Tef Improvement Project implements diverse tools and techniques.

Mutation breeding

Mutation breeding is a process which includes three steps, namely mutation induction, mutation detection and mutation utilization (Tadele et al. 2010). Mutation induction refers to the exposure of seeds or other parts of the plant to chemicals or radiation to induce random nucleotide mutations in the genome. To establish mutagenized populations, seeds of three improved tef varieties, namely Tsedey (DZ-Cr-37), Dukem (DZ-01974) and Kora (DZ-Cr-438 RIL 133B) were treated with the chemical ethyl methanesulfonate (EMS). The stock of seeds and the DNA from 10,000 mutagenized $\mathrm{M}_{2}$ populations from these three elite cultivars are available for screening for the trait(s) of interest. Screening of a mutagenized population for candidate lines based on their phenotype is a simple and effective strategy if the desired trait is readily observable. As lodging is one of the main production constraints for tef, screening was first applied to the discovery of semi-dwarf tef lines.

Primary screenings of these mutagenized populations have been made for various agronomic and nutritional traits at several research and higher-learning institutions (Table 1). While the majority of screenings have been done at the host institute at the University of Bern, screening for soil acidity was made at ARARI (Amhara Regional Agricultural Research Institute) in Ethiopia with the collaboration with the University of KwaZulu-Natal in South Africa (Ermias Abate, personal communication), while screening for altered starch content was done at the ETH Zurich (Wuyan Wang, personal communication) (Table 1, Fig. 4).

Tef accessions collected from diverse regions in Ethiopia also exhibited huge diversity for important agronomical and morphological traits (Assefa et al. 2015). A detailed study on 200 accessions collected from diverse agroecologies from major tef-growing areas showed substantial phenotypic diversity (Habte Jifar, personal communication).

\section{TILLING}

TILLING (Targeting Induced Local Lesion IN Genomes) is a high-throughput non-transgenic method that allows for screening single-base mutations in a specific gene over an entire mutagenized population (McCallum et al. 2000). The technique comprises the following steps: (i) mutagenesis, (ii) development of a non-chimeric population, (iii) preparation of a germplasm stock, (iv) DNA extraction and sample pooling, (v) population screening for induced mutations including validation, and (vi) evaluation of candidate mutants for desirable trait(s) (Tadele et al. 2010; Esfeld et al. 2013). Gene targets are found by using genes known to control the agronomic or nutritional traits of interest in other plants and/or from RNA-Seq experiments. Usually, successful candidates arise from knocking out a gene by inducing either a missense mutation or a stopcodon inducing mutation. Tef is an allotetraploid plant and therefore, in order to observe phenotypic effects, recessive mutations need to be induced in each of the homoeologous chromosomes, which then need to be combined by crossing. To find candidates for a semidwarf line, TILLING was implemented on 5,000 mutagenized families. Genes implicated in regulating plant height, particularly two genes from the gibberellic acid and brassinosteroid biosynthesis pathways were targeted. Of the 40 lines harboring mutations in either of these two genes, sequencing has thus far revealed 15 mutations with non-synonymous missense or nonsense mutations (Korinna Esfeld, personal communication).

In vitro regeneration

In vitro regeneration has applications in the embryo rescue technique which is important to circumvent the hybridization barrier between tef and wild species as well as in modern improvement techniques including CRISPR (Clustered Regularly Interspaced Short Palindromic Repeats) (Miao et al. 2013). We have optimized the technique for tef in which a fully grown plant is developed from immature embryos (PlazaWüthrich et al. 2015). Embryo rescue techniques are mostly used in crossing programs involving other 
Table 1 Primary screening and status of mutagenized tef populations developed at various Universities for diverse traits

\begin{tabular}{|c|c|c|c|c|}
\hline Trait of interest & $\begin{array}{l}\text { Background } \\
\text { genotype }\end{array}$ & Institution involved & Screening technique & Status \\
\hline Semi-dwarfism & $\begin{array}{l}\text { Tsedey, Dukem and } \\
\text { Kora }\end{array}$ & University of Bern & $\begin{array}{l}\text { TILLING and phenotypic } \\
\text { screening }\end{array}$ & $\begin{array}{l}\text { Semi-dwarf and lodging- } \\
\text { tolerant variety to be } \\
\text { released }\end{array}$ \\
\hline Drought tolerance & Tsedey and Dukem & University of Bern & Phenotypic screening & $\begin{array}{l}\text { Drought-tolerant variety at } \\
\text { the last stage of testing }\end{array}$ \\
\hline \multirow[t]{2}{*}{$\begin{array}{l}\text { Soil acidity } \\
\text { tolerance }\end{array}$} & Tsedey & $\begin{array}{l}\text { Kwazu-Natal- } \\
\text { ARARI }\end{array}$ & Phenotypic screening & $\begin{array}{l}\text { Promising candidate } \\
\text { obtained }\end{array}$ \\
\hline & Kora & University of Bern & Phenotypic screening & Validation of candidates \\
\hline $\begin{array}{l}\text { Soil salinity } \\
\text { tolerance }\end{array}$ & Kora & University of Bern & Phenotypic screening & Validation of candidates \\
\hline Herbicide tolerance & Tsedey and Dukem & University of Bern & Phenotypic screening & Validation of candidates \\
\hline Seed size & Tsedey and Kora & University of Bern & Phenotypic screening & Planned \\
\hline Starch content & Tsedey & ETH Zurich & TILLING & Validation of candidates \\
\hline
\end{tabular}

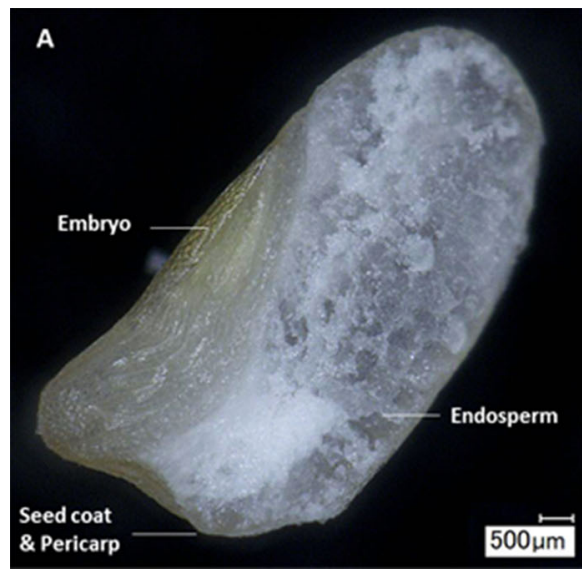

Fig. 4 Starch-rich seed of the tef variety Tsedey. a A single tef seed cut in half and observed using a VHX-5000 Keyence digital microscope; b The same seed after iodine-staining with Lugol's

plant species. At the present time, we are introgressing wild Eragrostis species with desirable traits to tef which will be followed by rescuing the embryos.

Tef seed pelleting

Seed pelleting involves adding some materials to the seed surface to change their size and/or shape to improve sowing. Seed pelleting is useful in tef husbandry as it facilitates row sowing of the tiny seeds. Figure 5 shows preliminary experiments from increasing the size of tef seeds through pelleting and

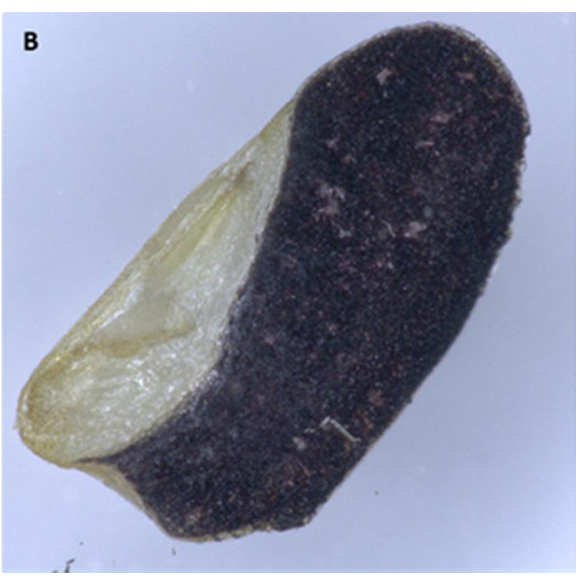

solution, which stains the starchy endosperm a blue-black color. (Color figure online)

the effect of different-sized pellets on the early establishment of tef plants. At present, the pelleting materials are inert and the primary function is in seed handling, however, in the future, pelleting materials can also contain compounds to boost seedling nutrition and to protect the seeds from pests and diseases. The pelleting project is a collaboration among Syngenta AG, Syngenta Foundation for Sustainable Agriculture, University of Bern and the Ethiopian Institute of Agricultural Research. Effort is being made to make the pelleting technology accessible and affordable to smallholder farmers in Ethiopia. 


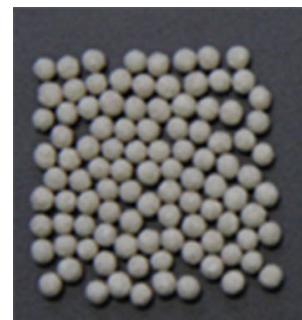

$20 x$

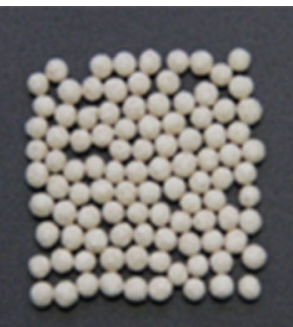

$15 x$
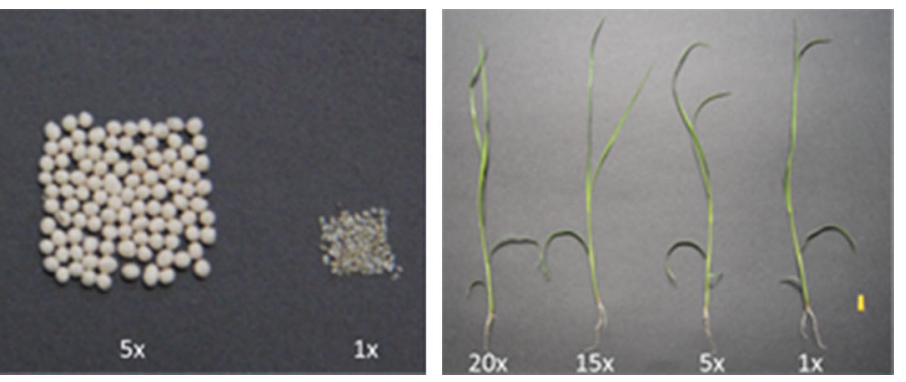

Fig. 5 Seed pelleting is useful in tef husbandry as it facilitates row sowing of the tiny seeds. a differing sizes of pelleted seeds by weight $(\times 20, \times 15, \times 5)$ compared to the naked seeds $(\times 1)$; b seed pelleting has no effect on the growth of tef seedlings. The

\section{Biomechanics}

In order to investigate the lodging-tolerance of diverse tef genotypes, we use a custom-made robot employing Cellular Force Microscopy (CFM) (Routier-Kierzkowska and Smith 2014). With this robot, 3-point bending is used to measure the stiffness of stem sections, while pushing is used to assess root anchorage strength. Information from these techniques is valuable for tef breeders as lodging resistance of the tef plants might be dependent on structural parameters of the plant. We are also collaborating with researchers at the University of Edinburgh, UK, to structurally prime tef plants via mild mechanical stimulation, e.g., stomping (Iida 2014). Such crop management strategies may bring about economical and immediate solutions for enhancing lodging resistance.

\section{Omics}

We have implemented a variety of omic techniques which are briefly described below.

\section{Whole genome sequencing}

The tef variety Tsedey was selected for whole-genome sequencing because it is early maturing and widely adapted. Genome sequencing has the following applications in tef improvement: (i) identification of primer sequences for gene amplification without resorting to other genomes or degenerate primers; (ii) isolation of tef's two homeologous sub-genomes, which is especially useful when designing, genome specific primers for high-throughput techniques such as TILLING; (iii)
Tef Pelleting Project is a collaborative work among SyngentaMaribo, Syngenta Foundation for Sustainable Agriculture, the University of Bern and the Ethiopian Institute of Agricultural Research

designing of genetic markers such as Single Nucleotide Polymorphisms (SNPs) and Simple Sequence Repeats (SSRs) which are used for marker-assisted breeding, for the construction of high density genetic maps and for linkage disequilibrium studies on diverse germplasms and; (iv) understanding the molecular basis of tef's tolerance to many abiotic and biotic stresses. Once obtained from tef, this knowledge can be transferred to other economically important crops.

\section{Transcriptome sequencing}

A normalized transcriptome library produced with 454 sequencing was sequenced to estimate the number of genes. In addition, RNA-Seq experiments were conducted using plants grown under control, waterlogging and drought conditions, as well as in developing seeds.

\section{MicroRNA sequencing}

The microRNAomes of two tissues (root and leaf) were determined for two tef genotypes subjected to either a two-week drought or normal watering. The two tef genotypes used for the study were a droughtsusceptible natural accession called Alba and a drought-resistant improved variety called Tsedey. For the identification of miRNAs important in the response to drought resistance, responses of the two tef cultivars were compared.

\section{Proteomics}

The response of tef to drought was investigated using quantitative proteomics measured with iTRAQ 
labeling in combination with mass spectroscopy. These data accompanied classical characterization of the physiological responses of tef to imposed changes in relative water content (RWC), such as electrolyte leakage and chlorophyll fluorescence measurements when tef tissues were dehydrated to $50 \%$ RWC as opposed to normally hydrated tissues with $80 \%$ RWC.

\section{Technology transfer: introgression and early variety development}

\section{Introgression}

Once candidate tef lines with desirable traits have been identified, further investigations are carried out in greenhouses and in the field. Confirmed candidate lines are then sent to the Ethiopian Institute of Agricultural Research (EIAR) for crossing, fieldtesting, and release to the farming community. In order to introduce desirable traits to the tef germplasm of popular and high-yielding lines, lodging-tolerant and drought-tolerant lines have been introgressed to a number of improved tef cultivars grown in Ethiopia. Table 2 shows some of the new candidates, their crosses and their positions in the pipeline. Candidate lines originating from the project have been used in $50 \%$ of the crosses in the National Tef Research Program due to their desirable traits such as lodgingand drought- tolerance. These candidate lines have been introgressed to popular improved tef varieties such as Quncho, Kora and Magna.

\section{Early variety development}

Different progenies of the crosses are evaluated for several generations at Debre Zeit Agricultural Research Center in Ethiopia. Once initial screenings of the genotypes have been completed, those with enhanced performance are promoted for multi-location evaluation at sites representative of traditional tef growing areas (Table 3). In 2016, 16 experiments, each containing 80 genotypes were tested at 24 representative sites. The sites belong to several research and higher learning institutions and range in altitude from $1400 \mathrm{~m}$ asl at Wolenchiti to $2500 \mathrm{~m}$ asl at Bichena and Shambu. Hence, they represent the huge diversity in the agroecology of the country. These breeding experiments are designed and dispatched to collaborating centers via the National Tef Research Program based at the Debre Zeit Agricultural Research Center. Candidate materials with enhanced performance at several locations over several seasons are then promoted to variety verification stage where they are grown on larger plots to be investigated by the National Variety Release Committee. Collaboration with the EIAR has enabled the evaluation of promising lines via on-station and on-farm field-testing through the Farmer Participatory Research program (Belay et al. 2006) where the best performing lines are recommended for a release to the farming communities. Farmers, development agents and other relevant stakeholders are invited to events organized regularly to introduce new tef varieties.

Based on increased demand from both the domestic and global markets for tef grain, the Ethiopian government has recently planned to expand tef cultivation in the western and eastern parts of the country where tef is not usually grown. To identify genotypes best suited for these areas with diverse environmental conditions, for the first time in 2016, 47 tef genotypes from the Tef Improvement Project have been investigated at 10 non-traditional locations out of which five are rain-fed and five irrigated (Table 4).

\section{Achievements of the project}

Major successes of the Tef Improvement Project are briefly indicated below.

The first semi-dwarf and lodging-tolerant tef

We have identified and characterized two novel tef mutants (namely kegne and kinde) both with semidwarf stature and lodging-tolerant properties. The mutation in kegne is due to a point mutation in the $\alpha$ Tubulin 1 gene which co-segregates with the mutant phenotype and serves as a marker in breeding (Jost et al. 2015) (Fig. 6a, Table 2). The kegne mutant attains 50 to $70 \%$ of the height of the parental line. This modest height reduction is optimal for lodging resistance and grain yield for human consumption as well as maintaining sufficient straw for livestock feed. The putative mutation in kinde has been discovered using a modified MutMap technique and is currently being confirmed (Muluneh Tamiru, personal communication). Two lodging-tolerant and semi-dwarf tef 
Table 2 Partial view of crosses made to candidate tef lines developed by the Tef Improvement Project

\begin{tabular}{|c|c|c|c|c|c|}
\hline Candidate line & Desirable trait & Crossed to & Used as & Year of crossing & Current status \\
\hline \multirow[t]{5}{*}{ kegne } & \multirow[t]{5}{*}{ Lodging-tolerant } & Quncho & M & 2010 & NVT \\
\hline & & Magna & $\mathrm{M}$ & 2010 & NVT \\
\hline & & Tsedey & M & 2010 & $\mathrm{~F}_{3}$ seeds \\
\hline & & Key Murri & M & 2011 & NVT \\
\hline & & DZ-01-2785 & M & 2013 & $\mathrm{~F}_{7}$ seeds \\
\hline \multirow[t]{14}{*}{ kinde } & \multirow[t]{14}{*}{ Lodging-tolerant } & Quncho & M & 2010 & NVT \\
\hline & & Key Murri & $\mathrm{F}$ & 2011 & NVT \\
\hline & & Dukem/Quncho & M & 2011 & $\mathrm{~F}_{3}$ seeds \\
\hline & & Tsedey & M & 2013 & $\mathrm{~F}_{4}$ seeds \\
\hline & & DZ-01-192 & $\mathrm{F}$ & 2013 & $\mathrm{~F}_{4}$ seeds \\
\hline & & DZ-01-192 & M & 2014 & $\mathrm{~F}_{3}$ seeds \\
\hline & & Rosea & M & 2013 & $\mathrm{~F}_{4}$ seeds \\
\hline & & DZ-01-2786 & M & 2014 & $\mathrm{~F}_{3}$ seeds \\
\hline & & DZ-01-99 & $\mathrm{F}$ & 2014 & $\mathrm{~F}_{6}$ seeds \\
\hline & & DZ-01-2785 & $\mathrm{F}$ & 2914 & $\mathrm{~F}_{6}$ seeds \\
\hline & & Alba & M & 2014 & $\mathrm{~F}_{6}$ seeds \\
\hline & & Magna & M & 2014 & $\mathrm{~F}_{3}$ seeds \\
\hline & & Boset & M & 2014 & $\mathrm{~F}_{3}$ seeds \\
\hline & & Kora & M & 2013 & $\mathrm{~F}_{3}$ seeds \\
\hline \multirow{5}{*}{$\begin{array}{l}\text { RIL44 } \\
\text { (Key Murri x kinde) }\end{array}$} & \multirow[t]{5}{*}{ Semi-dwarf/lodging tolerance } & Dukem & $\mathrm{F}$ & 2016 & $\mathrm{~F}_{1}$ seeds \\
\hline & & Magna & $\mathrm{F}$ & 2016 & $\mathrm{~F}_{1}$ seeds \\
\hline & & Magna & M & 2016 & $\mathrm{~F}_{1}$ seeds \\
\hline & & DZ-01-99 & $\mathrm{F}$ & 2016 & $\mathrm{~F}_{1}$ seeds \\
\hline & & RIL181 & M & 2016 & $\mathrm{~F}_{1}$ seeds \\
\hline \multirow{6}{*}{$\begin{array}{l}\text { RIL302 } \\
\text { (Key Murri x kinde) }\end{array}$} & \multirow[t]{6}{*}{ Semi-dwarf/lodging tolerance } & Kora & M & 2016 & $\mathrm{~F}_{1}$ seeds \\
\hline & & Kora & $\mathrm{F}$ & 2016 & $\mathrm{~F}_{1}$ seeds \\
\hline & & Magna & $\mathrm{F}$ & 2016 & $\mathrm{~F}_{1}$ seeds \\
\hline & & DZ-01-99 & M & 2016 & $\mathrm{~F}_{1}$ seeds \\
\hline & & Dukem & M & 2016 & $\mathrm{~F}_{1}$ seeds \\
\hline & & RIL181 & M & 2016 & $\mathrm{~F}_{1}$ seeds \\
\hline \multirow[t]{6}{*}{$d t t 2$} & \multirow[t]{6}{*}{ Drought-tolerance } & Quncho & M & 2013 & OVT \\
\hline & & Key Murri & $\mathrm{F}$ & 2013 & F8 \\
\hline & & Kegne & $\mathrm{F}$ & 2013 & $\mathrm{~F}_{3}$ seeds \\
\hline & & Dtt13 & $\mathrm{F}$ & 2013 & OVT \\
\hline & & Magna & $\mathrm{F}$ & 2013 & $\mathrm{~F}_{3}$ seeds \\
\hline & & Magna & M & 2013 & $\mathrm{~F}_{3}$ seeds \\
\hline \multirow[t]{4}{*}{$d t 113$} & \multirow[t]{4}{*}{ Drought-tolerance } & $D t t 2$ & M & 2013 & OVT \\
\hline & & Magna & $\mathrm{F}$ & 2013 & $\mathrm{~F}_{3}$ seeds \\
\hline & & Key Murri & $\mathrm{F}$ & 2013 & $\mathrm{~F}_{3}$ seeds \\
\hline & & Bosset & M & 2014 & $\mathrm{~F}_{3}$ seeds \\
\hline \multirow[t]{3}{*}{$t d t 4-15$} & \multirow[t]{3}{*}{ Terminal drought tolerance } & Magna & M & 2016 & $\mathrm{~F}_{3}$ seeds \\
\hline & & Kora & M & 2016 & $\mathrm{~F}_{1}$ seeds \\
\hline & & Dukem & M & 2016 & $\mathrm{~F}_{1}$ seeds \\
\hline
\end{tabular}


Table 2 continued

\begin{tabular}{llllll}
\hline Candidate line & Desirable trait & Crossed to & Used as & Year of crossing & Current status \\
\hline tdt4-19 & Terminal drought tolerance & Bosset & $\mathrm{M}$ & 2016 & $\mathrm{~F}_{1}$ seeds \\
& & Dukem & $\mathrm{M}$ & 2016 & $\mathrm{~F}_{1}$ seeds \\
& Kora & $\mathrm{M}$ & 2016 & $\mathrm{~F}_{1}$ seeds \\
& RIL44 & $\mathrm{M}$ & 2016 & $\mathrm{~F}_{1}$ seeds \\
\hline
\end{tabular}

$M$ male, $F$ female, $N V T$, national variety trial, $O V T$ observation variety trial

cultivars (namely RIL 44 and RIL 302) (Fig. 6b, c) which were obtained by crossing kinde with Kay Murri (a landrace with a strong stem) have been tested for several seasons at representative locations and will soon be submitted for variety registration.

A new variety with special morphological properties has been evaluated by the National Variety Release Committee and approved for release in March 2017. This release marks a milestone for the Tef Improvement Project as it is the first candidate to obtain formal status as a new variety. The new variety RIL-181 will be named 'Tesfa', the Amharic word for 'Hope', based on the suggestion of farmers who evaluated it. The performance of Tesfa in terms of grain yield and shoot biomass are shown in Fig. 7. Although the yield and biomass of RIL-181 (Tesfa) are comparable to both the popular variety $Q u n c h o$ as well as local varieties, the new variety possesses unique and desirable properties including the absence of shattering, a thick and strong culm and compact panicles. These properties, especially the increased culm strength, mean that the new variety can not only be cultivated in rainfed agriculture like other tef varieties, but can also potentially be grown in large-scale irrigated farms with mechanical harvesting. These are the main reasons for the approval of Tesfa variety by the National Variety Committee although the height reduction and lodging tolerance of this particular variety were not significantly different from the existing tef varieties (data not shown).

In order to disseminate seeds of the new variety to large numbers of farmers, it has been planned that both public and private sectors will multiply the seed, including lead farmers with experience in producing high quality seed. The Debre Zeit Research Center has a well-established and proven tef technology dissemination system involving multiple sectors and stakeholders.

\section{Drought tolerant tef}

We focus on the drought which normally occurs during the early developmental stage of the tef plant when the rain stops for 2-3 weeks soon after crop germination. We selected tef lines that are tolerant to this kind of moisture scarcity while the original tef lines are severely stressed. Screening the mutagenized population enabled us to obtain several candidate tef lines with enhanced drought tolerance (Table 1). Among these, $d t t 2$ (drought tolerant tef 2) and $d t t$ 13 have shown particularly promising performance. The unique morphological difference between these $d t t$ lines and the parental line is stomata. The stomata at the adaxial or upper side of the two $d t t$ lines are smaller in both size and number compared to the original tef line (Fig. 6d-f). These small-sized stomata in $d t t$ lines might contribute towards making the plant more tolerant to drought as less water is lost through transpiration (Sonia Plaza-Wüthrich, personal communication). Both $d t t$ lines were introgressed to highyielding improved cultivars and these introgressions have now reached $\mathrm{F}_{8}$ and are in Observation Variety Trials (OVT) where they will be tested at multiple sites in drought prone areas (Table 2).

The first tef genome

A draft genome with 47-fold coverage with Illumina HiSeq 2000 and seven-fold coverage with 454-FLX pyrosequencing was generated (Cannarozzi et al. 2014). Assembly and scaffolding resulted in a genome size of $688 \mathrm{Mbp}$, roughly $95 \%$ of the $1 \mathrm{C}$ genome size estimated by flow cytometry (Hundera et al. 2000; Ayele et al. 1996). The information from the sequencing is being utilized in identifying and isolating genes responsible for useful agronomic and nutritional traits. A considerable number of genetic markers particularly 
Table 3 Traditional tef-growing locations in Ethiopia where germplasms from the Tef Improvement Project have been evaluated under diverse categories in 2016 after crossing to improved tef varieties

\begin{tabular}{|c|c|c|c|c|c|}
\hline Center/site & Institute $^{\mathrm{a}}$ & $\begin{array}{l}\text { Distance and direction } \\
\text { from Addis Ababa }\end{array}$ & $\begin{array}{l}\text { Altitude } \\
\text { (m a.s.l.) }\end{array}$ & Climate & Experiments tested ${ }^{\mathrm{b}}$ \\
\hline Adadi Mariam & EIAR & $55 \mathrm{~km} \mathrm{~S}$ & 1900 & Sub-humid & 16 \\
\hline Adet & ARARI & $445 \mathrm{~km} \mathrm{NW}$ & 2240 & Moist-cool & 16 \\
\hline Akaki & EIAR & $10 \mathrm{~km} \mathrm{~S}$ & 2300 & Cool-wet & $1,2,5,6,7,8,9,11,13,14,16$ \\
\hline Alem Tena & EIAR & $110 \mathrm{~km} \mathrm{~S}$ & 1650 & Semi-arid & $3,4,10,12,15$ \\
\hline Ambo & EIAR & $115 \mathrm{~km} \mathrm{~W}$ & 2185 & Temperate & 16 \\
\hline Asosa & EIAR & $655 \mathrm{~km} \mathrm{~W}$ & 1590 & Warm to sub-humid & 15 \\
\hline Axsum & TARI & $955 \mathrm{~km} \mathrm{~N}$ & 2100 & Semi-arid & 15,16 \\
\hline Bichena & ARARI & $270 \mathrm{~km} \mathrm{NW}$ & 2500 & Cool-wet & 16 \\
\hline Chefe Donsa & EIAR & $40 \mathrm{~km} \mathrm{SE}$ & 2400 & Cool-wet & $1,2,5,11,13,14,16$ \\
\hline Debre Zeit-light soil & EIAR & $45 \mathrm{~km} \mathrm{~S}$ & 1800 & Temperate & $3,14,15,16$ \\
\hline Debre Zeit-Black soil & EIAR & $45 \mathrm{~km} \mathrm{~S}$ & 1800 & Temperate & $1,2,3,4,5,10,11,12,13,14,15,16$ \\
\hline Dhera & EIAR & $122 \mathrm{~km} \mathrm{SE}$ & 1680 & Semi-arid & $6,7,9,15$ \\
\hline Hirna & $\mathrm{HU}$ & $365 \mathrm{~km} \mathrm{E}$ & 1775 & Cool-wet & 15,16 \\
\hline Holetta & EIAR & $35 \mathrm{~km} \mathrm{~W}$ & 2390 & Cool-wet & 16 \\
\hline Ginchi & EIAR & $90 \mathrm{~km} \mathrm{~W}$ & 2200 & Tepid-moist & 16 \\
\hline Jimma & EIAR & $365 \mathrm{~km} \mathrm{SW}$ & 1760 & Sub-humid & 16 \\
\hline Mehoni & TARI & $635 \mathrm{~km} \mathrm{~N}$ & 2400 & Arid & 15 \\
\hline Melkassa & EIAR & 115 km SE & 1550 & Semi-arid & $8,10,15$ \\
\hline Minjar & EIAR & $110 \mathrm{~km} \mathrm{SE}$ & 1800 & Semi-arid to moist & $4,10,11,12,13,14,15,16$ \\
\hline Shambu & OARI & $305 \mathrm{~km} \mathrm{~W}$ & 2500 & Cool-wet & 16 \\
\hline Simada & ARARI & 770 km NW & 2470 & Semi-arid & 15 \\
\hline Sirinka & ARARI & $510 \mathrm{~km} \mathrm{~N}$ & 1850 & Semi-arid & 15 \\
\hline Wolenchiti & EIAR & $120 \mathrm{~km} \mathrm{SE}$ & 1400 & Semi-arid & 15 \\
\hline Wolkite & WKU & $190 \mathrm{~km} \mathrm{SW}$ & 1920 & Sub-humid & 16 \\
\hline
\end{tabular}

anstitutes: ARARI Amhara Regional Agricultural Research Institute, EIAR Ethiopian Institute Agricultural Research, $H U$ Haramaya University, OARI Oromia Agricultural Research Institute, SARI South Agricultural Research Institute, TARI Tigray Agricultural Research Institute, WKU Wolkite University

${ }^{\mathbf{b}}$ Experiments: (1) Observation Variety Trial—Late Set I; (2) Observation Variety Trial—Late Set II; (3) Observation Variety Trial— Early Set; (4) Observation Variety Trial-Semi-dwarf; (5) Observation Variety Trial—Late Set Semi-dwarf; (6) Observation Variety Trial-Drought Tolerance I; (7) Observation Variety Trial—Drought Tolerance II; (8) Observation Variety Trial—Drought Tolerance III; (9) Observation Variety Trial—Drought Tolerance IV (10) Preliminary Variety Trial—Early set I; (11) Preliminary Variety Trial-Late Set IV; (12) Preliminary Variety Trial—semi-Dwarf, Early Set; (13) Preliminary Variety Trial—Late Set III; (14) Preliminary Variety Trial—Semi-dwarf; (15) National Variety Trial—Early set; (16) National Variety Trial—Late Set III-I

SSRs (also known as microsatellites) have been identified (Table 5).

Other key findings in tef in the area of omics are:

\section{Transcriptome}

Sequencing of the transcriptome resulted in approximately 38,000 transcripts. Prediction of coding regions resulted in 33,000 genes which were then annotated and for which orthologous genes were found between tef, sorghum, and rice (Fig. 8a) (Cannarozzi et al. 2014).
RNA-Seq

RNA-Seq experiments using waterlogging and drought treatments revealed genes differentially regulated under these two conditions ( $<<0.01)$ (Fig. 8b) (Gina Cannarozzi, personal communication). Furthermore, RNA-Seq experiments have been used to analyze the transcriptome of developing seeds to identify genes involved in endosperm starch biosynthesis. These experiments provide targets for TILLING as well as for miRNA analyses. 
Table 4 Non-traditional tef-growing locations in Ethiopia where germplasms from the Tef Improvement Project have been evaluated in 2016 after crossing to improved tef varieties

\begin{tabular}{|c|c|c|c|c|}
\hline Center/site & Institute $^{\mathrm{a}}$ & $\begin{array}{l}\text { Distance and direction } \\
\text { from Addis Ababa }\end{array}$ & $\begin{array}{l}\text { Altitude } \\
\text { (m a.s.l.) }\end{array}$ & Climate \\
\hline \multicolumn{5}{|l|}{ Rain-fed sites } \\
\hline Abobo & GARI & $750 \mathrm{~km} \mathrm{~W}$ & 500 & Sub-humid \\
\hline Humera & TARI & 975 km NW & 600 & Warm-moist lowland \\
\hline Jinka & SARI & $580 \mathrm{~km} \mathrm{SW}$ & 1500 & Sub-humid lowland \\
\hline Metema & ARARI & 900 km NW & 690 & Sub-humid \\
\hline Pawe & EIAR & $575 \mathrm{~km} \mathrm{NW}$ & 1000 & Sub-humid \\
\hline \multicolumn{5}{|l|}{ Irrigated sites } \\
\hline Jigjiga & JJU & $600 \mathrm{~km} \mathrm{E}$ & 1600 & Semi-arid \\
\hline Kobo & ARARI & $590 \mathrm{~km} \mathrm{~N}$ & 1470 & Warm-moist \\
\hline Koga & ARARI & $665 \mathrm{~km} \mathrm{NW}$ & 1980 & Tepid-moist \\
\hline Shewa Robit & ARARI & $210 \mathrm{~km} \mathrm{~N}$ & 1280 & Semi-arid \\
\hline Werer & EIAR & $280 \mathrm{~km} \mathrm{NE}$ & 750 & Warm-arid \\
\hline
\end{tabular}

anstitutes: ARARI Amhara Regional Agricultural Research Institute, EIAR Ethiopian Institute Agricultural Research, GARI Gambella Agricultural Research Institute, JJU Jigjga University, SARI South Agricultural Research Institute, TARI Tigray Agricultural Research Institute

\section{MicroRNA}

MicroRNA sequencing was done for roots and leaves of two tef cultivars, one drought susceptible (Alba) and one drought tolerant (Tsedey), under drought and control conditions. Comparison of differentially regulated miRNAs from the two cultivars revealed several homologs of known miRNAs similarly regulated in both cultivars and a few that were differentially regulated and may contribute to differences in drought tolerance. Prediction of the targets of these miRNAs resulted in the identification of many transcription factors that may be potential targets for improvement of drought resistance (Federico Martinelli, personal communication). In addition, a total of 147 novel and unique putative miRNA precursors with mature miRNA sequences were identified.

\section{Proteomics}

Proteins involved in the biotic and abiotic stress responses, signaling, transport, cellular homeostasis and pentose metabolic processes were found to be more abundant during drought while proteins involved in ROS producing processes such as photosynthetic reactions, cell wall catabolism, manganese transport and homeostasis, the synthesis of sugars and cell wall modification were less abundant (Kamies et al. 2017). This is the first reported proteomic study of tef.

\section{Release and acceptance of improved tef varieties}

For the scaling-up of improved tef technologies to farmers, ten lead farmers were selected in 2015 based on their technical expertise and their level of technology acceptance. These lead farmers represented three districts (namely, Ada, Minjar-Shenkora and MoretnaJirru) in the Central Highlands of Ethiopia where tef is the major crop (Bekele et al. 2017). In 2016, the number of lead farmers participating in the scaling-up technology increased to 45 from four districts. Participating farmers had a high acceptance of the improved technologies especially the new seeds. Other farmers in the respective communities were also invited to observe the performance of new tef varieties managed by the lead farmers and requests to participate in next year's scaling-up of the project are very high. Although this initial phase of scaling-up involved a limited number of farmers, the improved seeds from the currently participating 45 lead farmers could be distributed to $10,000-15,000$ farmers in the coming 
Fig. 6 Major achievements of the Tef Improvement Project. a-c lodging-tolerant and high yielding tef varieties; d-f droughttolerant tef $(d t t)$. a semidwarf and lodging-tolerant variety (right) compared to the original line (left). Plant height (b) and lodging index (c) of the two candidate lines, RIL44 and RIL302, compared to the local variety Boset. $\mathbf{d} d t t$ (right) and original (left) lines under moisture scare condition. Stomata number (e) and stomata length (f) of the adaxial or upper side of the two $d t t$ lines and the original Tsedey variety. Values with the same letter are not significantly different $(\mathrm{p}<0.05)$ from each other using a MannWhitney test
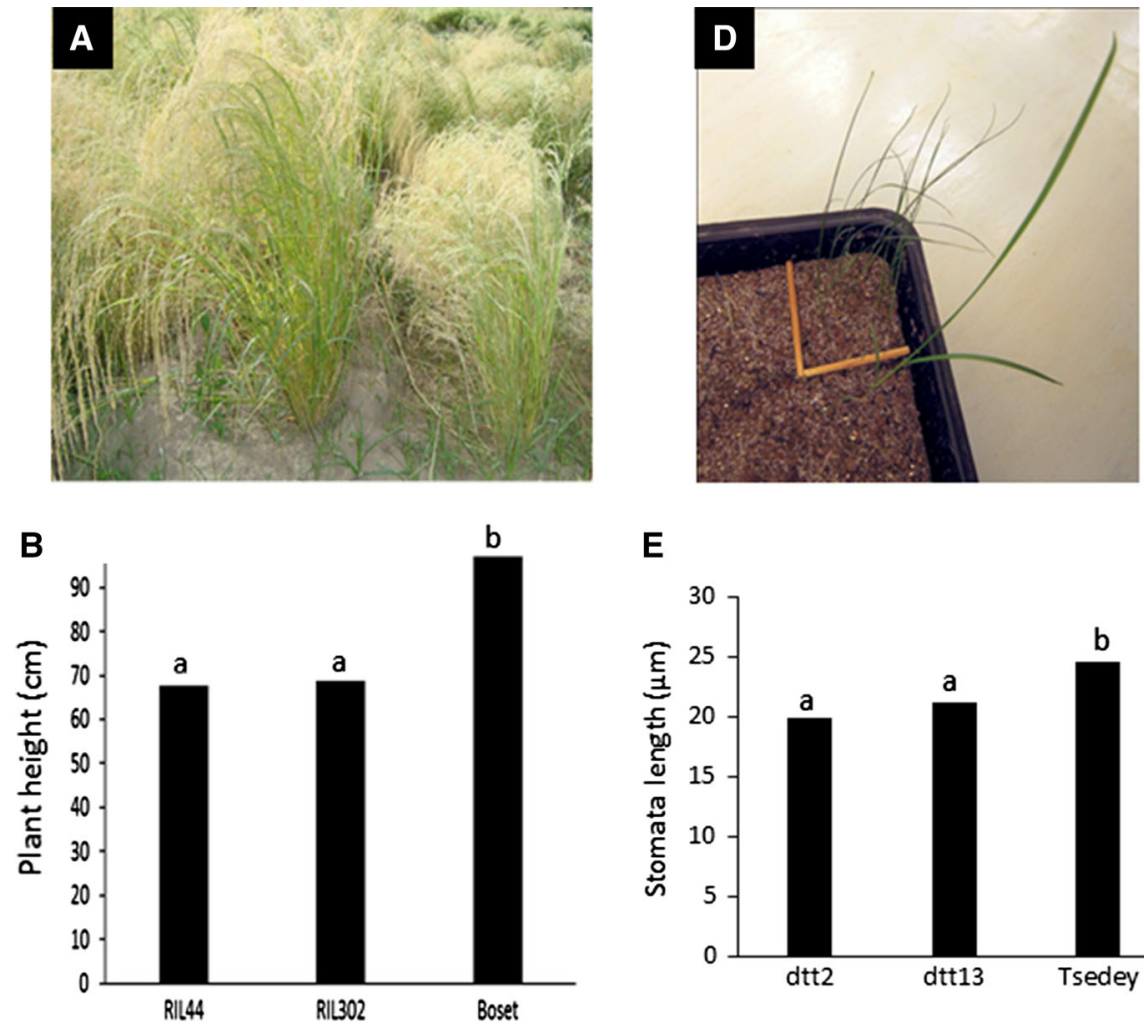

E

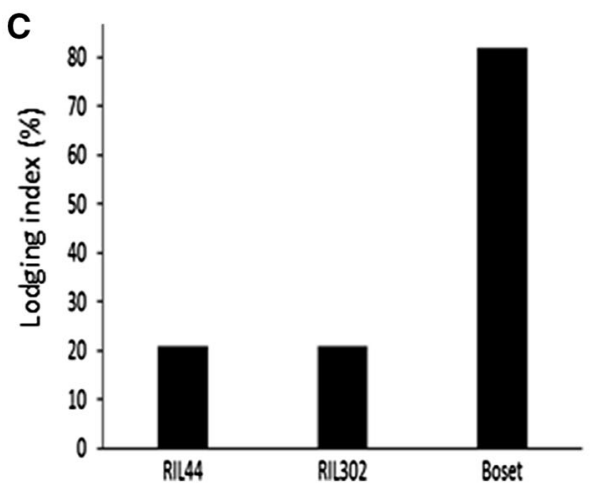

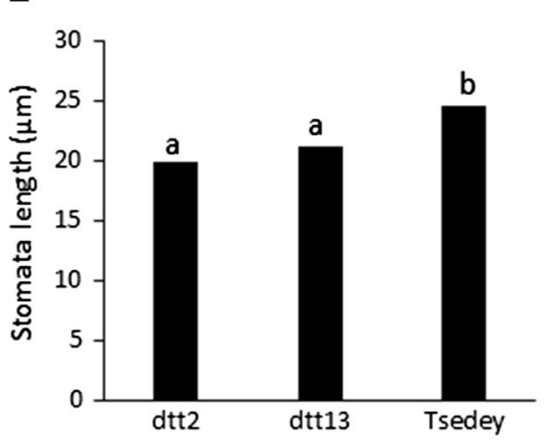

$\mathbf{F}$

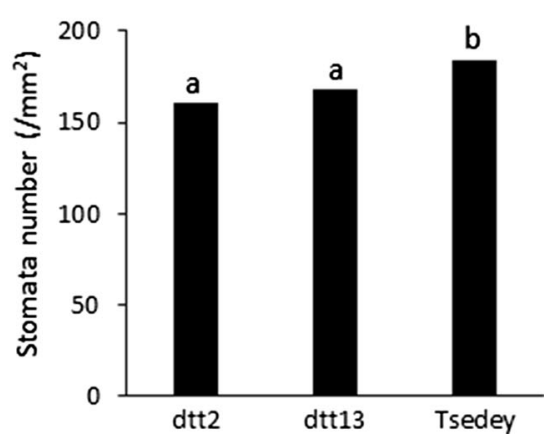

cropping season. The main reason for the high number of farmers able to participate is the small amount of seed required for sowing tef (as small as $5 \mathrm{~kg} \mathrm{ha}^{-1}$ ) and small farm size per household (0.25-0.5 ha).

\section{Partnerships}

The partnership with the Ethiopian Agricultural Research System is critical to the success of our project since it ensures the release and distribution of improved seeds to the subsistence tef farmers in
Ethiopia. Field testing at the on-station and on-farm sites is continuing and the best performing cultivars will be released to farmers after evaluation by the Ethiopian National Variety Release Committee. Financial and technical support from the Syngenta Foundation for Sustainable Agriculture and hosting by the Institute of Plant Science at the University of Bern are the cornerstones of the project. Interest in the program from other research institutions and the media helps to raise the profile of tef research and generate momentum. In general, the collaboration established by the Tef Improvement Project involves a 

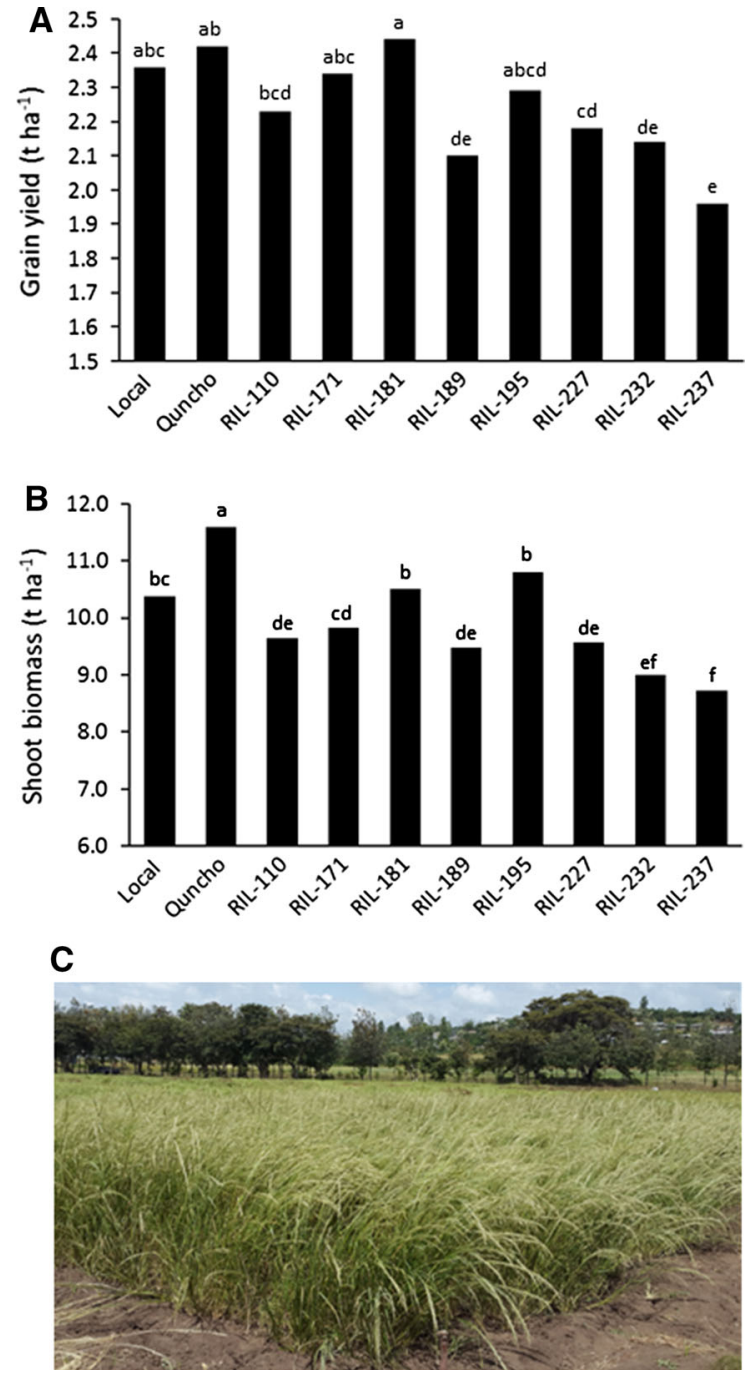

Fig. 7 The performance of several tef varieties including a new line (RIL-181 or Tesfa) approved for release by the National Variety Release Committee in Ethiopia. Average grain yield (a) and shoot biomass (b) of 10 lines including eight candidate RILs and the widely cultivated Quncho variety tested at six field sites in Ethiopia. The sites were Adet, Debre Zeit black Vertisols, Debre Zeit light soil, Chefe-Donsa, Holetta and Ginchi. RIL lines were tested for more than eight generations after crossing to the improved variety or to the local cultivar. RILs investigated were selected from the following crosses: mutant line kinde with Kay muri (RILs 110, 181, 227, 232 and 237), mutant line kinde with Quncho (RILs 171 and 189), and mutant line kegne with Kay murri (RIL 195). Means followed by same letter were not significantly different from each other $(\mathrm{p}<0.05$, ANOVA). c RIL-181 (Tesfa) grown in the field at Debre Zeit in black Vertisols

prototype of a private-public partnership (PPP). The involvement of farmers at early selection stages is important in order to breed towards the preferences of end-users (i.e. farmers and consumers). Once the new varieties are approved for release, seed multiplication involves public-, public-private enterprises, and/or privately owned seed companies. In addition, model farmers with know-how in the handling of improved seeds are becoming more involved in multiplying and disseminating the seeds to other farmers.

Globally, the dissemination of improved technologies to farmers in developing countries have been successfully made for locally important crops. Among these, the contributions of the Generation Challenge Programme (GCP) and its close associate Integrated Breeding Platform (IBP) are worthwhile to mention. GCP is a research initiative with more than 200 partners in 54 countries which focuses on exploring plant genetic diversity and developing crops with improved stress tolerance (Frison and Demers 2014; GCP 2017). The major crops of GCP's focus are root and tuber (cassava), legumes (beans, chickpea, cowpea, pigeon pea and groundnut) and cereals (maize, rice, sorghum and wheat).

On the other hand, IBP is a service provider established by GCP to closely work with plant breeders in developing countries. The platform facilitates the implementation of various stages of a breeding programme by serving as a vehicle for dissemination of knowledge and technology, enabling access to breeding materials and providing costeffective high-throughput laboratory services (IBP 2017). The IBP aims to increase the effectiveness and efficiency of up to 500 plant breeding programmes across the world in 5 years with a specific focus on smallholder farmers in the developing world (IBP 2017).

\section{Outlook and prospects}

Food security is the main concern in Africa especially in Ethiopia, as the production and productivity of crops are under continuous threat (Nichola 2006). Indigenous crops can contribute significantly to food security under the present scenario of increasing world population and changing climate (Naylor et al. 2004). These crops play key roles in the livelihood of smallholder farmers and consumers in Africa since they outperform the major world crops in terms of stress tolerance under the extreme soil and climate conditions prevalent on the continent (Sanginga et al. 2000; 
Table 5 SSR

(microsatellite) markers present in the tef genome indicating summary statistics and size distribution

\begin{tabular}{|c|c|c|}
\hline \multicolumn{3}{|c|}{ Summary statistics } \\
\hline \multicolumn{2}{|c|}{ Total number of sequences examined } & 405,558 \\
\hline \multicolumn{2}{|c|}{ Total genome size (bp) } & $672,766,097$ \\
\hline \multicolumn{2}{|c|}{ Total number of identified SSRs } & 162,124 \\
\hline \multicolumn{2}{|c|}{ Number of scaffolds containing SSR } & 23,431 \\
\hline \multicolumn{2}{|c|}{ Number of scaffolds containing more than one SSR } & 9024 \\
\hline Repeat length & No of required repeats & No of repeats in tef genome \\
\hline 1 & 10 & 110,513 \\
\hline 2 & 6 & 27,880 \\
\hline 3 & 5 & 19,116 \\
\hline 4 & 5 & 2008 \\
\hline 5 & 4 & 2179 \\
\hline 6 & 4 & 428 \\
\hline
\end{tabular}

Campell 1997; Brandt 1997; Alemaw and Teklewold 1995). Unlike the introduced global crops, these indigenous crops have the major advantage that they fit well into the general socio-economic and ecological context of the region (Tadele 2009; Tadele and Assefa 2012).

The immediate goal of the Tef Improvement Project is to improve crop productivity by tackling major yield limiting factors using state-of-the-art methodology. The ultimate objective, however, is to improve the livelihood of small-scale farmers and consumers in Ethiopia through ensuring food and nutrition security in a country where persistent food insecurity remains a real and major challenge. Hence, the Project will contribute to Ethiopia's economic development through increasing the productivity of the country's most important crop.

We recently (March 2017) reached a milestone- the first release of a cultivar produced in the Tef Improvement Project to Ethiopian consumers. The new release, Tesfa, a cultivar developed by crossing an existing cultivar to a candidate discovered through phenotypic screening of a mutagenized population. Many other candidates are progressing through the pipeline and should be released in the coming years. Cultivars tolerant to soil acidity (especially aluminum toxicity), salinity, and non-selective herbicide are in the pipeline at various stages of laboratory research, field testing and crossing.

The overall success of the project depends on the scale of dissemination and adoption of the new cultivars and for this purpose, the importance of a close working relationships between the University of Bern and the National Agricultural Research System of Ethiopia cannot be overstated.

The increase in productivity and production of tef will substantially reduce if not eliminate the import of grains. Ethiopia annually imports large amounts of both cereal grain and flour. For instance, in the year 2013, the country imported 1.7 million tons of wheat, sorghum and maize at the cost of 712 million USD (FAOSTAT 2015). In order to develop improved crops in general (and tef specifically) for the prevailing and expected challenging environment, we suggest to improve productivity through investing in research and development.

\section{Conclusions}

This paper describes a collaborative effort between scientists in Europe and Africa to implement a pipeline for the development of new tef cultivars using both traditional and molecular breeding and to make these novel varieties available to the Ethiopian farmers. After testing under controlled conditions, the generated technology (i.e. the lines with the desirable traits) are transferred to the Ethiopian Institute of Agricultural Research (EIAR) for introgression and field testing. Each candidate line undergoes vigorous field testing at various locations and under different conditions. This cooperation is critical to the success of the project since it ensures the release and distribution of improved seeds to the subsistence farmers in 
A
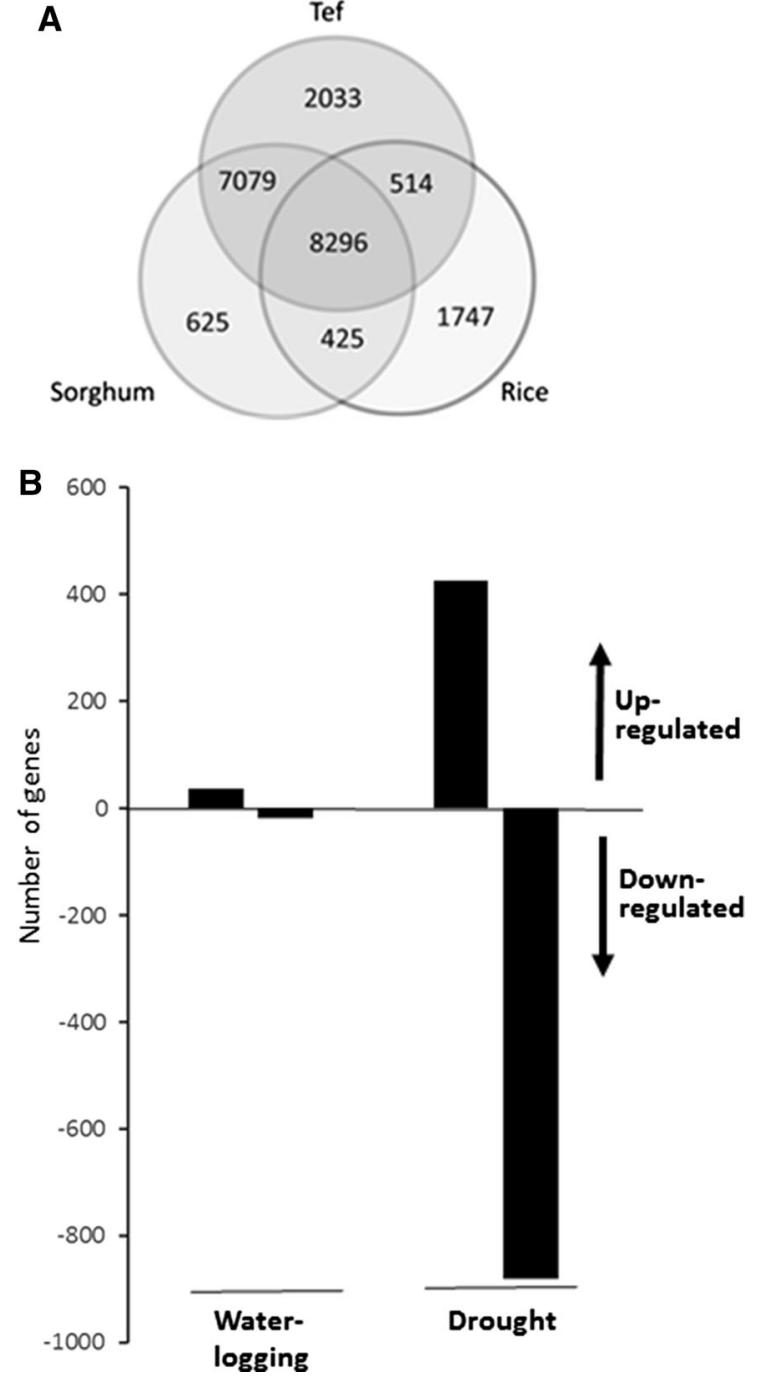

Fig. 8 Genome-scale expression of tef genes. a The number of orthologous groups of genes between tef, sorghum, and rice. b the number of differentially regulated tef genes under drought and waterlogging conditions

Ethiopia. So far, several semi-dwarf candidate lines with lodging-tolerance and drought-tolerance obtained from the screenings are being introgressed and evaluated in Ethiopia. Farmers are also involved in the selection procedure starting from the on-station research until the release of the improved variety in socalled Farmer Participatory Research. Now that the pipeline has been established and works successfully, further desirable traits such as soil acidity tolerance, increased seed size and improved grain quality are being addressed and the strategy applied to other orphan crops. With improved assembly and annotation of the tef genome sequence, it will be possible to harness the rich natural variation present in the tef germplasm collections using appropriate techniques. The long-term commitment by the private funding organization is also key to the success of the project. The combination of substantial private funding with a farmer-participatory approach in breeding is a particular merit of the Tef Improvement Project which deserves attention for future initiatives.

Acknowledgements The Tef Improvement Project has benefited greatly from long-term support granted by the Syngenta Foundation for Sustainable Agriculture (SFSA). Special thanks goes to Dr. Andrew Bennet and Dr. Marco Ferroni (former SFSA Executive Directors) and Dr. Simon Winter (current SFSA Executive Director), Dr. Andres Binder, Mr. Paul Castle and Prof. Cris Kuhlemeier for unwavering support. The Biomechanics project is supported by SystemsX.ch while the seed pelleting by Syngenta and Maribo Seed. The Institute of Plant Sciences, University of Bern is acknowledged for hosting and supporting the project. Research into tef seed starch is provided by EU Marie Skłodowska-Curie action PITNGA-2013-608422-IDP BRIDGES. Special thanks to collaborators at various research centers in Ethiopia and Christopher Ball and his team as well as Anhui $\mathrm{Wu}$, Electine Magoye and Mirjam Schnell at the University of Bern for technical support.

Open Access This article is distributed under the terms of the Creative Commons Attribution 4.0 International License (http:// creativecommons.org/licenses/by/4.0/), which permits unrestricted use, distribution, and reproduction in any medium, provided you give appropriate credit to the original author(s) and the source, provide a link to the Creative Commons license, and indicate if changes were made.

\section{References}

Abebe Y, Bogale A, Hambidge KM, Stoecker BJ, Bailey K, Gibson RS (2007) Phytate, zinc, iron and calcium content of selected raw and prepared foods consumed in rural Sidama, Southern Ethiopia, and implications for bioavailability. J Food Compos Anal 20(3-4):161-168. https://doi. org/10.1016/j.jfca.2006.09.003

Alemaw G, Teklewold A (1995) An agronomic and seed-quality evaluation of noug (Guizotia abyssinica Cass.) germplasm in Ethiopia. Plant Breed 114(4):375-376

Assefa K, Yu JK, Zeid M, Belay G, Tefera H, Sorrells ME (2011) Breeding tef [Eragrostis tef (Zucc.) trotter]: conventional and molecular approaches. Plant Breed 130(1):1-9. https://doi.org/10.1111/j.1439-0523.2010. 01782.x

Assefa K, Cannarozzi G, Girma D, Kamies R, Chanyalew S, Plaza-Wuthrich S, Blosch R, Rindisbacher A, Rafudeen S, Tadele Z (2015) Genetic diversity in tef [Eragrostis tef 
(Zucc.) Trotter]. Front. Plant Sci. https://doi.org/10.3389/ Fpls.2015.00177

AU (2005) 10 Percent National Budget Allocation to Agriculture Development: Maputo Declaration on Agriculture and Food Security. African Union (AU)

Ayele M, Dolezel J, VanDuren M, Brunner H, ZapataArias FJ (1996) Flow cytometric analysis of nuclear genome of the Ethiopian cereal Tef [Eragrostis tef(Zucc) Trotter]. Genetica 98(2):211-215

Bekele A, Chanyalew S, Damte T, Assefa K, Tadele Z (2017) Lead farmers approach in disseminating improved tef production technologies. Ethiop J Agric Sci 27(1):25-36

Belay G, Tefera H, Tadesse B, Metaferia G, Jarra D, Tadesse T (2006) Participatory variety selection in the Ethiopian cereal tef (Eragrostis tef). Exp Agr 42(1):91-101

Brandt SA (1997) The "tree against hunger" : enset-based agricultural system in Ethiopia. American Association for the Advancement of Science, Washington DC

Bultosa G, Hall AN, Taylor JRN (2002) Physico-chemical characterization of grain tef [Eragrostis tef (Zucc.) Trotter] starch. Starch-Starke 54(10):461-468

Campell CG (1997) Grass pea (Lathyrus sativus L.). Promoting the conservarion and use of underutilized and neglected crops 18. IPK, Gartersleben/IPGRI, Rome

Cannarozzi G, Plaza-Wuthrich S, Esfeld K, Larti S, Wilson YS, Girma D, de Castro E, Chanyalew S, Blosch R, Farinelli L, Lyons E, Schneider M, Falquet L, Kuhlemeier C, Assefa K, Tadele Z (2014) Genome and transcriptome sequencing identifies breeding targets in the orphan crop tef (Eragrostis tef). BMC Genom 15:581. https://doi.org/10.1186/14712164-15-581

Chandrasekara A, Shahidi F (2011) Antiproliferative potential and DNA scission inhibitory activity of phenolics from whole millet grains. J Funct Foods 3(3):159-170. https:// doi.org/10.1016/j.jff.2011.03.008

Chandrashekar A (2010) Finger Millet Eleusine coracana. Adv Food Nutr Res 59:215-262. https://doi.org/10.1016/ S1043-4526(10)59006-5

CSA (2015) Agricultural sample survey 2014/2015. volumve I. Report on areaand production of major crops. Statistical Bulletin 578. Central Statistical Agency (CSA), Addis Ababa

Ejeta G (2010) African Green Revolution needn't be a mirage. Science 327(5967):831-832. https://doi.org/10.1126/ science. 1187152

Esfeld K, Uauy C, Tadele Z (2013) Application of TILLING for orphan crop improvement. In: Jain SM, Gupta SD (eds) Biotechnology of neglected and underutilized crops. Springer, New York, pp 83-113

FAOSTAT (2015) Trade. http://faostat.fao.org/site/342/default. aspx. Accessed Jan 52015

FAOSTAT (2016) FAO (Food and Agricultural Organization) Statistical Data. FAO Statistics Division http://faostat3. fao.org/home/E. Accessed April 182016

Frison E, Demers N (2014) Building a global genetic resource system. In: Tuberosa R, Graner A, Frison E (eds) Genomics of plant genetic resouirces. Vol. I. managing, sequencing and mining genetic resources. Springer, Dordrecht

Fungo R (2009) Potential of bananas in alleviating micronutrient eficiencies in the great lakes region of East Africa. Afr Crop Sci Conf Proc 9:8
GCP (2017) Generation challenge programme: Partnerships in modern crop breeding for food security. https://www. generationcp.org/. Accessed Oct 232017

Godfray HC, Beddington JR, Crute IR, Haddad L, Lawrence D, Muir JF, Pretty J, Robinson S, Thomas SM, Toulmin C (2010) Food security: the challenge of feeding 9 billion people. Science 327(5967):812-818. https://doi.org/10. 1126/science. 1185383

Hundera F, Arumuganathan K, Baenziger P (2000) Determination of relative nuclear DNA content of tef [Eragrostis tef (Zucc.) Trotter] using flow cytometry. J Genet Breed 54:165-168

IBP (2017) Integrated breeding platform. https://www. integratedbreeding.net/. Accessed Oct 232017

Iida H (2014) Mugifumi, a beneficial farm work of adding mechanical stress by treading to wheat and barley seedlings. Front Plant Sci 5:453. https://doi.org/10.3389/fpls. 2014.00453

IPGRI (2004) Promoting fonio production in West and Central Africa through germplasm management and improvement of post harvest technology. Project number: 2000.7860.0001.00 International Plant Genetic Resources Institute (IPGRI), Benin, Africa

Jeffrey J (2015) Will Ethiopia's teff be the next 'super grain'? BBC Business. April 2, 2015. www.bbc.com/news/ business-32128441

Jost M, Esfeld K, Burian A, Cannarozzi G, Chanyalew S, Kuhlemeier C, Assefa K, Tadele Z (2015) Semi-dwarfism and lodging tolerance in tef (Eragrostis tef) is linked to a mutation in the alpha-Tubulin 1 gene. $\mathrm{J} \operatorname{Exp}$ Bot 66:933-944. https://doi.org/10.1093/jxb/eru452

Kamies R, Farrant JM, Tadele Z, Cannarozzi G, Rafudeen MS (2017) A proteomic approach to investigate the drought response in the orphan crop Eragrostis tef. Proteomes 5(4):32

McCallum CM, Comai L, Greene EA, Henikoff S (2000) Targeted screening for induced mutations. Nat Biotechnol 18(4):455-457. https://doi.org/10.1038/74542

Miao J, Guo DS, Zhang JZ, Huang QP, Qin GJ, Zhang X, Wan JM, Gu HY, Qu LJ (2013) Targeted mutagenesis in rice using CRISPR-Cas system. Cell Res 23(10):1233-1236. https://doi.org/10.1038/Cr.2013.123

NAP (1996) Lost crops of Africa, volume I: grains. National Academy Press, Washington DC

NAP (ed) (2006) Lost crops of Africa; volume II: vegetables. National Academies Press, Washington DC

Naylor RL, Falcon WP, Goodman RM, Jahn MM, Sengooba T, Tefera H, Nelson RJ (2004) Biotechnology in the developing world: a case for increased investments in orphan crops. Food Policy 29(1):15-44. https://doi.org/10.1016/j. foodpol.2004.01.002

Nichola T (2006) The food security problem in Ethiopia- a supply side analysis. S Afr J Econ 74(2):315-322. https:// doi.org/10.1111/j.1813-6982.2006.00072.x

Plaza-Wüthrich S, Blösch R, Tadele Z (2015) Efficiency of in vitro regeneration is dependent on the genotype and size of explant in tef [Eragrostis tef (Zucc.) Trotter]. advances in Crop. Sci Technol 3:3. https://doi.org/10.4172/23298863.1000179 
Provost C, Jobson E (2014) Move over quinoa, Ethiopia's teff poised to be next big super grain. The Guardian Newspaper. January 23, 2014

Routier-Kierzkowska AL, Smith RS (2014) Mechanical measurements on living plant cells by micro-indentation with cellular force microscopy. Methods Mol Biol 1080:135-146. https://doi.org/10.1007/978-1-62703-6436_11

Sanginga N, Lyasse O, Singh BB (2000) Phosphorus use efficiency and nitrogen balance of cowpea breeding lines in a low P soil of the derived savanna zone in West Africa. Plant Soil 220(1-2):119-128

Spaenij-Dekking L, Kooy-Winkelaar Y, Koning F (2005) The Ethiopian cereal tef in celiac disease. $\mathrm{N}$ Engl J Med 353:1748-1749. https://doi.org/10.1056/NEJMc051492
Tadele Z (2009) Role of Orphan Crops in Enhancing and Diversifying Food Production in Africa. African Technology Development Forum (ATDF) Journal 6 (3/4):9-15

Tadele Z, Assefa K (2012) Increasing food production in africa by boosting the productivity of understudied crops. Agronomy 2(4):240-283

Tadele Z, Mba C, Till BJ (2010) TILLING for mutations in model plants and crops. In: Jain SM, Brar DS (eds) Molecular Techniques in Crop Improvement: 2nd Edition Springer, New York, pp 307-332

Valenzuela H, Smith J (2002) Cowpea. University of Hawaii, Honolulu. Sustainable Agriculture DA-GM-6

Williams JT, Haq N (2000) Global research on underutilised crops: an assessment of current activities and proposals for enhanced cooperation. Southampton, UK 